\title{
Hygrophorus betulae, a new species described from subalpine birch forest in Finland
}

\section{Ellen Larsson ${ }^{1,2,}$, Katriina Bendiksen ${ }^{3}$}

1 University of Gothenburg, Department of Biological and Environmental Sciences, Box 461, SE-40530 Göteborg, Sweden

2 Gothenburg Global Biodiversity Centre, Box 461, 40530 Göteborg, Sweden

${ }^{3}$ University of Oslo, Natural History Museum, P.O. Box Blindern,

0318 Oslo, Norway

* Corresponding author:

ellen.larsson@bioenv.gu.se

Keywords: host preference, Hygrophoraceae, molecular systematics, taxonomy, woodwaxes

Article info:

Received: 22 November 2018

Accepted: 29 July 2019

Published online: 11 March 2020

Corresponding Editor: Riikka Linnakoski

\section{Abstract}

A new species, Hygrophorus betulae, associated with Betula pubescens is described from the subalpine zone of northern Finland. The molecular phylogenetic analysis shows that it is closely related to $H$. mesotephrus, a species described from England and associated with Fagus. In morphology $H$. betulae is characterized by the small glutinous basidiomata and the pale pileus with an olive-grey disc zone. The colour of the disc zone is similar to that of H. olivaceoalbus. The species seems to be rare or may be overlooked because of the small and pale appearance. 


\section{Introduction}

During field-work in subalpine birch forests in Kilpisjärvi, Northwest Finland, a small Hygrophorus Fr. species was observed and collected from late August to middle of September in 1979, 1983 and 1985. The species was found reminiscent of $H$. mesotephrus Berk. \& Broome and H. olivaceoalbus (Fr.) Fr., but the basidiomata were smaller and the ecology did not fit with the information given in the species descriptions. It was first determined to $H$. cf. mesotephrus, as no other proper name could be found in the current available literature (Hesler \& Smith 1963, Larsson et al. 2011, Kovalenko 2012). Many years later the ITS sequence data was generated from the specimens for comparison with molecular data of similar species in Hygrophorus. The sequence was then found to be unique and gave support that it likely represents an undescribed species.

The three available collections were all collected at a single site and most of them within a radius of one meter. In 1985 one basidiomata was also found $18-20 \mathrm{~m}$ from the first spot. The locality on the lower southwest slope of mountain Saana was one of five permanent study plots of the dryish birch forest type (Cornus-Empetrum-Myrtillus). The plots were part of a nationwide fungus yield project (1976 - 1978) and were monitored weekly by the second author from the end of July to the end of September in 1976 - 1983, and for a shorter period in $1984-85$.

The northwest corner of Finland is the only part of the country which reaches the Scandinavian mountain range. Rocks of Cambro-Silurian origin are here resting upon the Precambrian bedrock. The main part of the Saana mountain in Kilpisjärvi consists of shale, but below the top plateau of fell schist there is a dolomite layer (Uusinoka 1980). The Betula pubescens Ehrh. forests around upper Kilpisjärvi belong mostly to oceanic vegetation section where the driest, lichen dominated forests are lacking, and dry Empetrum dominated forests are rare (Hämet-Ahti 1963). The most typical for this section are dryish birch forests dominated by trivial species like Empetrum nigrum L. subsp. hermaphroditum (Hagerup) Böcher, Vaccinium myrtillus L. and Chamaepericlymenum suecicum (L.) Graebn. (= Cornus suecica L.). However, local depressions in trivial forests on lower slopes of Saana are influenced by calcareous spring water that also gives growth conditions for more nutrient demanding plants and fungi.

In both Sweden and Norway there are numerous subalpine birch forests with a similar ecology that we would imagine could be suitable for the species described here. Despite efforts to recollect material at the site in Kilpisjärvi in both 2013 and 2017, and making a call for it in the Swedish Mycological Society Journal (Larsson \& Bendiksen 2011), no additional material has been found.

To make the small Hygrophorus species from subalpine birch forest more visible we here give the species a name and describe it as new to science. We hope that people will encounter it and report it in the future.

\section{Material and methods}

\section{Morphological methods}

The majority of the sequenced specimens in this study were collected by the authors. The holotype of the here described Hygrophorus betulae, and one additional collection were received as loan from herbarium OULU. Permission to extract DNA and sequence the ITS region was granted. Abbreviations of herbaria follow Index Herbariorum (http://sweetgum.nybg.org/science/ih/).

Macro-morphological characters and the ecology were observed in the field, and fresh basidiomata photographed. Micro-morphological characters were measured from dried material mounted in Congo red NH3 solution at 1000x and 400x magnifications. Photos of micro-morpholgical characters were made using an Axioskop 2 (Zeiss, Oberkochen, Germany) light microscope and the AxioVision software (http://www.zeiss.com/microscopy/int/ home.html). For each specimen the length and width of a minimum of 30 spores were measured and the ratio calculated $(\mathrm{Q}=$ length/width). In addition, 10 basidia and sterigmata, as well as hyphae of trama, pilei- and stipitipellis were measured.

\section{Molecular methods}

Nine specimens from Fennoscandia were targeted for sequencing. In addition, ITS sequence data of species from section Olivaceoumbrini (Bataille) Konr. \& M. were included from previous studies, $H$. agathosmus (Fr.) Fr., H. odoratus A.H. Sm. \& Hesler, H. exiguus E. Larss., E. Campo \& M. Carbone, H. lati- 


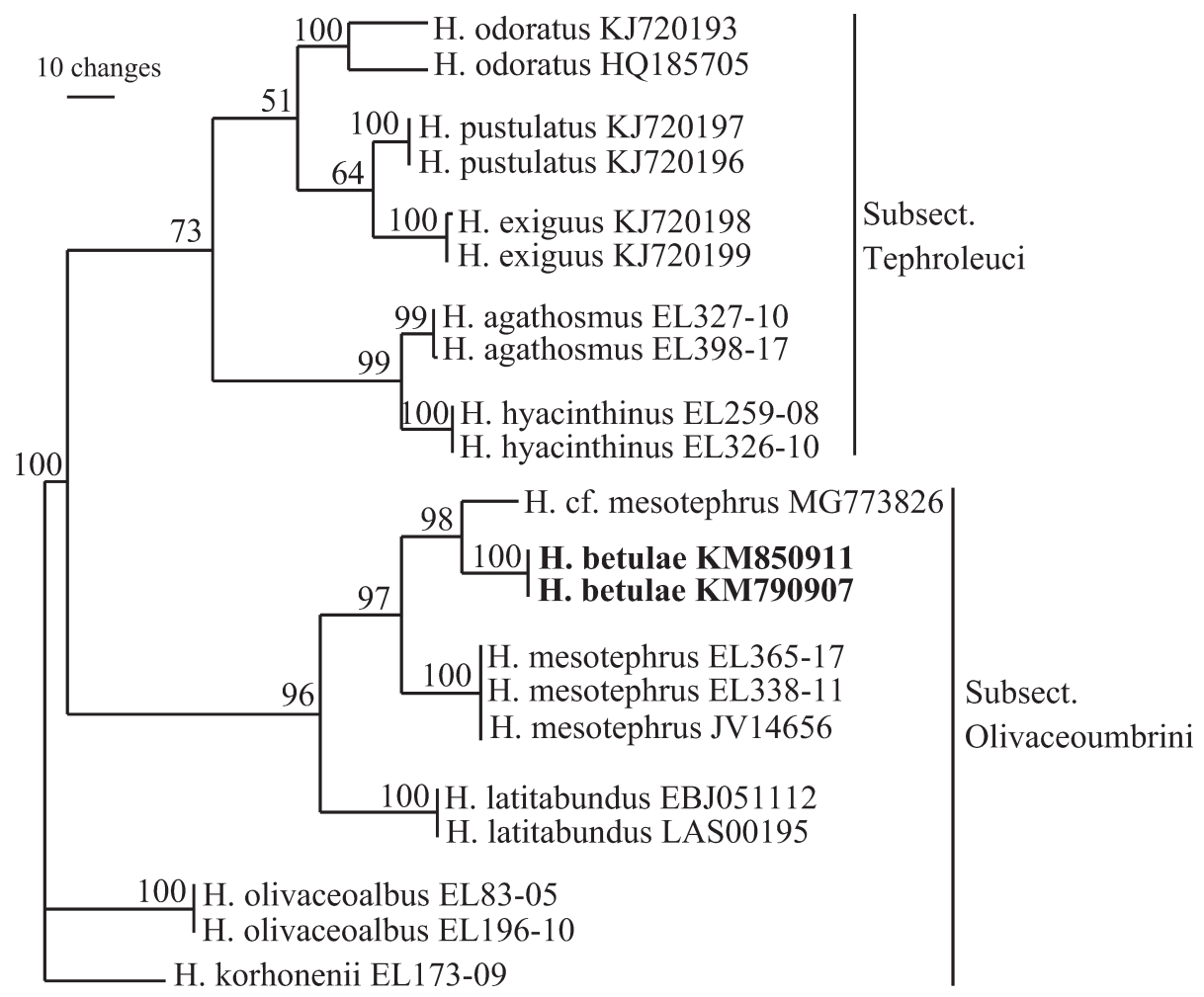

Fig. 1. Phylogram showing the phylogenetic position of $\mathrm{H}$. betulae in Hygrophorus subsection Olivaceoumbrini, based on ITS sequence data. Bootstrap values are indicated on branches. Clades discussed in the text are indicated with bars and species epithets. Sequences originating from type specimens are marked.

tabundus Britzelm., H. mesothephrus, H. olivaceoalbus and H. pustulatus (Pers.) Fr. (Larsson et al. 2014; Lodge et al. 2014, Larsson et al. 2018). The ITS sequence of the new described species was also blasted against GenBank (Clark et al. 2016) to search for additional data generated from curated specimens or from environmental samples as soil and ectomycorrhizae. Only one sequence was found and added to the data set, submitted under the name H. cf. mesotephrus (MG773826). Sequence data of $H$. korhonenii Harmaja was selected as out-group for rooting of trees.

Sequences from the complete internal transcribed spacer (ITS) region of the nuclear ribosomal DNA were generated. Protocols for DNA extraction, PCR and primers used follow Larsson et al. (2018). Sequences were edited and assembled using Se- quencher 5.1 (Gene Codes, Ann Arbor, Michigan). The generated sequences have been deposited in GenBank (MK123933- MK123941). Alignment was performed using the L-INS-i strategy as implemented in MAFFT v. 7.017 (Katoh \& Standley 2013). The alignment was adjusted using Aliview 1.17.1 (Larsson 2014). For inferring phylogenetic relationships among species heuristic searches for the most parsimonious trees were performed using PAUP* (Swofford 2003). All transformations were considered unordered and equally weighted. Heuristic searches with 1,000 random-addition sequence replicates and TBR branch swapping were performed. Relative robustness of clades was assessed by the bootstrap method using 1,000 heuristic search replicates with 10 random taxon addition sequence replicates and TBR branch swapping. 


\section{Results}

The aligned complete dataset consisted of 21 sequences and 696 characters. After exclusion of ambiguous regions from the beginning and the end of the data set 614 characters remained for the analysis. Of these, 422 were constant, 26 were variable but parsimony uninformative, and 166 (27\%) were parsimony informative. The maximum parsimony analysis yielded two equally most parsimonious trees (length $=326$ steps, $\mathrm{CI}=0.7853$, and RI $=0.8839$ ) . One of the trees is presented as a phylogram in Fig. 1.

The bootstrap analysis recovered nine terminal clades with strong bootstrap support and one single branch. The clades correspond to $H$. odoratus (100\%), H. agathosmus (99\%), H. hyacinthinus (100\%), H. pustulatus (100\%), H. exiguus (100\%), H. mesotephrus (100\%), H. latitabundus (100\%), H. olivaceoalbus (100\%), and the new species $H$. betulae (100\%). The single branch with sequence data originating from North America is recovered with strong support close to H. betulae (98\%), Fig. 1.

\section{Taxonomy}

Hygrophorus betulae K. Bendiksen \& E. Larss. sp. nova.

- Figs. 2, 3C, 4

MycoBank no.: MB 828697

DIAGNOSIS: Small-sized species of subsection Olivaceoumbrini, resembling $H$. mesothphrus but differs by the somewhat smaller basidiomata, the pale whitish pileus with an olive-grey disc zone, and being associated with B. pubescens. So far only known from Kilpisjärvi, in the subalpine zone in Northern Finland.

TYPUS: FINLAND. Enontekiön Lappi, Enontekiö, Kilpisjärvi, Saana. Lower SW slope, about $1 \mathrm{~km}$. SE of the biological station. Subalpine birch forest of Cornus-Empetrum-Myrtillus type. Grid $27^{\circ} \mathrm{E}$ 7674:253 [69.0395249 ${ }^{\circ} \mathrm{N}, 20.81949^{\circ} \mathrm{E}$ ], alt. $510 \mathrm{~m}$ a.s.l., 11.IX.1985, leg. Katriina Metsänheimo (holotype OULU, isotype - GB, GenBank Acc. No. MK123936).

ETYMOLOGY: Refers to the ecology, associated with Betula pubescens.
PILEUS 26-35 $\mathrm{mm}$ in diam, convex when young, then plano-convex to flattened, to somewhat depressed in the centre, pale whitish with an olive-grey tint and with a distinct darker olivaceous-grey centre, rough to finely scaly, strongly glutinous when moist. Lamellae adnate to subdecurrent, $\mathrm{L}=26-32$, subdistant, thick, waxy, with lamellulae, richly veined, white to cream coloured. STIPE 50-75 $\times$ 5-7 mm, cylindrical or slenderly subfusiform, tapering towards the base, at apex white, dry, first pruinose with minute floccules, with age smooth, below glutinous of light greyish velum, context whitish, at base pale yellowish-brown. Taste and smell indistinct. Spore deposit white.

SPORES [ $\mathrm{n}=125]$ elliptical to ovoid, with an obtuse hilar appendage, smooth, hyaline, inamyloid, (8.5-) $10.1-10.2-10.3(-11.7) \times(4.8-)$ 6.0-6.1-6.2 (-6.9) $\mu \mathrm{m}$, average $\mathrm{Q}=1.65-1.68-1.70$. BASIDIA, mainly 4-spored, a few 1 or 2-spored, narrowly clavate, (33)42-47(54) × 6-8(9) $\mu \mathrm{m}$, sterigmata 6-8 $\mu \mathrm{m}$ long.

GILL trama bilateral, composed of interwoven thinwalled cylindrical inflated hyphae 10-12 $\mu \mathrm{m}$ wide with terminal end cells up to $25 \mu \mathrm{m}$ wide. PILEIPELLIS an ixotrichoderm up to $300 \mu \mathrm{m}$ thick; made up of loosely arranged interwoven, branched hyphae 1.5-5.5 $\mu \mathrm{m}$ wide, in matrix smooth, hyaline or with intracellular pigments, upper layer very loosely interwoven, hyaline and pigmented hyphae, with extracellular granules in matrix. SUBPELLIS composed of densely arranged, sub-parallel interwoven inflated hyphae up to $25 \mu \mathrm{m}$ broad. STIPITIPELLIS a ixotrichoderm, up to $200 \mu \mathrm{m}$ thick, made up of 3.5-5.5 $\mu \mathrm{m}$ wide interwoven branched hyphae, with scattered free end cells, smooth, hyaline, or with intracellular pigments. STIPITITRAMA of hyaline more or less parallel interwoven hyphae 5.5-8 $\mu \mathrm{m}$ wide. FLOCCULES at apex made up of compact erect interwoven cylindrical branched hyphae, 3-5 $\mu \mathrm{m}$ wide, with slightly enlarged end cells up to 6.5 $\mu \mathrm{m}$ wide.

CLAMP CONNECTIONS none or few, present in hymenial tissues.

MATERIAL STUDIED: FINLAND. Enontekiön Lappi, Enontekiö, Kilpisjärvi, Saana. Lower SW slope, about $1 \mathrm{~km}$. SE of the biological station. Sub- 

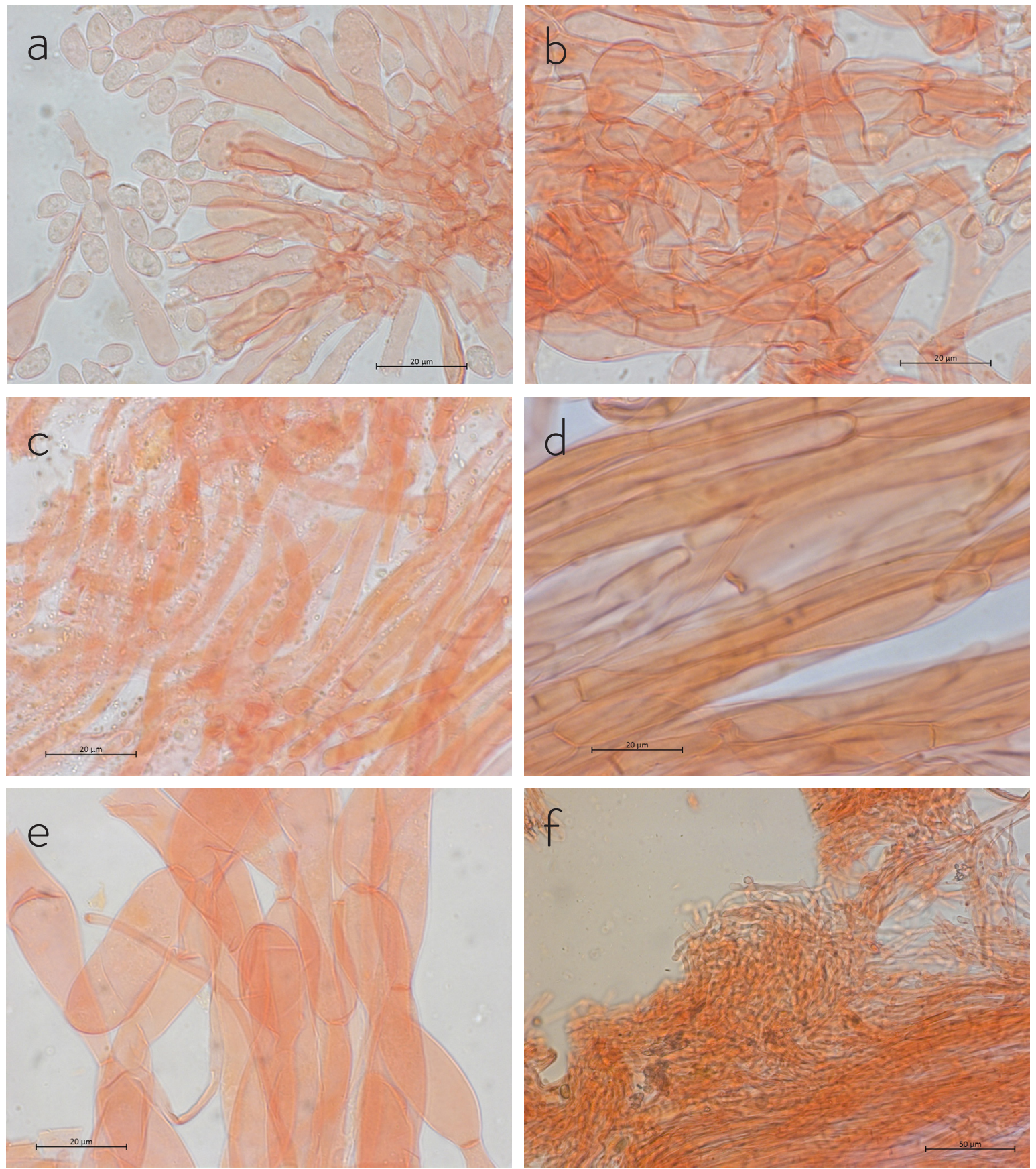

Fig. 2. Micromorphology of the holotype of H. betulae. a: basidia and spores from the lamellae edge (scale bar $20 \mu \mathrm{m}$ ), b: inflated hyphae from the hymenophoral trama (scale bar $20 \mu \mathrm{m})$, c: pilpeipellis hyphae with cellular and extracellular granules in matrix (scale bar $20 \mu \mathrm{m}$ ), d: parallel hyphae of stipititrama (scale bar 20 $\mu \mathrm{m}$ ), e: inflated hyphae from the subpileitrama (scale bar $20 \mu \mathrm{m}$ ), f: floccule at stipe apex, with erect interwoven hyphae and somewhat enlarged end cells (scale bar $50 \mu \mathrm{m}$ ). 

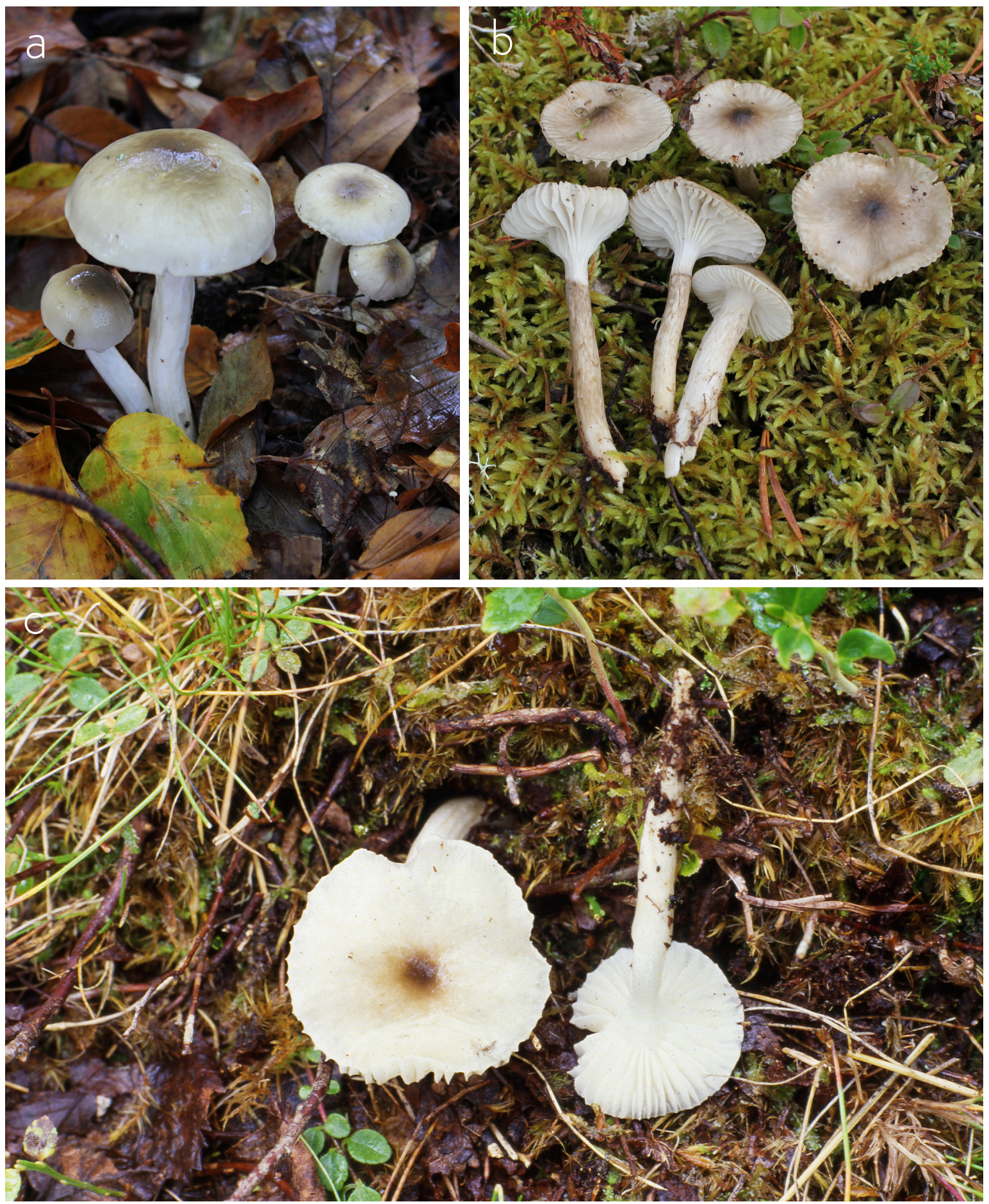

Fig. 3. Basidiomata of a: Hygrophorus mesothephrus (EL398-17, GB), b: H. olivaceoalbus (EL323-10, GB), c: the holotype of H. betulae (Katriina Metsänheimo 11.IX.1985, OULU). 
alpine birch forest of Cornus-Empetrum-Myrtillus type. Grid $27^{\circ} \mathrm{E} 7674: 253$, alt. $510 \mathrm{~m}$ a.s.l., 7.IX.1979, leg. Katriina Metsänheimo (OULU, GenBank Acc. No. MK123937); ibidem, 19.IX.1979, leg. Katriina Metsänheimo (O-F-370584)

ADDITIONAL MATERIAL STUDIED: Hygrophorus mesotephrus. DENMARK. Møn, Møns Klinteskov, E. part of the island, Fagus sylvatica on limestone, 19.IX.1998, leg. Jukka Vauras 14656F (TURA, GenBank Acc. No. MK123933); SWEDEN. Bohuslän, Tossene, Hogsäms NR, under Fagus sylvatica on calcareous soil, 26.IX.2017, leg. Ellen Larsson 365-17 (GB, GenBank Acc. No. MK123934); Skredsvik, under Fagus sylvatica on calcareous soil, 7.X.2011, leg. Ellen Larsson 338-11 (GB, GenBank Acc. No. MK123935).

Hygrophorus olivaceoalbus. FINLAND. Tavastia australis, Etelä-Häme, Ruovesi, under Picea abies, 5.IX.2005. leg. Ellen Larsson 83-05 (GB, GenBank Acc. No. MK123940); SWEDEN. Jämtland, Revsund, Ammerön, coniferous forest on calacreous soil, 26.VIII.2010, leg. Ellen Larsson 196-10 (GB).

Hygrophorus korhonenii. NORWAY. Nord-Trøndelag, Steinkjer, Skrattåsen, under Picea abies, 5.IX.2009.leg Ellen Larsson 173-09 (GB, GenBank Acc. No. MK123941)

Hygrophorus latitabundus. SWEDEN. Gotland, Eksta, Ekstakusten NR, Pinus sylvestris on calacer- ous ground, 23.IX.2000, leg. Leif and Anita Stridvall 00/195 (GB-0063940, GenBank Acc. No. MK123939); Skansudd, 12.XI.2005, Elsa Bohus-Jensen (GB0068803, GenBank Acc. No. MK123938).

\section{Discussion, ecology and distribution}

In recent years increased attention has been paid to hidden species and genetic diversity within $\mathrm{Hy}$ grophorus. Names previously applied to collections from a broad and often intercontinental geographic distribution range have by use of molecular data been shown to consist of several species as in $H$. hypothejus (Moreau et al. 2018) and H. agathosmus (Larsson et al. 2018). These studies also demonstrate that Hygrophorus species often have rather strict host preferences.

In this paper we describe $H$. betulae based on three collections made from 1979 to 1985 at a single locality in the subalpine zone in Northwest Finland. This still poorly known species is well characterized by both morphology and ITS sequence data. It seems to be rare as very few observations have been made despite that several efforts to recollect it have been made both at the type locality and at similar localities in the Scandinavian mountains. It may also
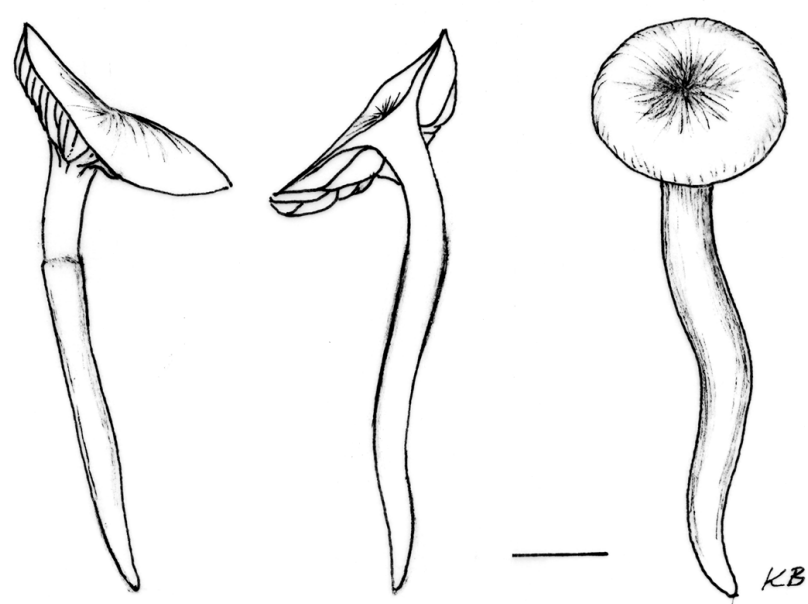

Fig. 4. Cross-section of a mature and outline of a young basidiomata of the holotype of $H$. betulae (Katriina Metsänheimo 11.IX.1985, OULU). Scale bar $=1 \mathrm{~cm}$ 


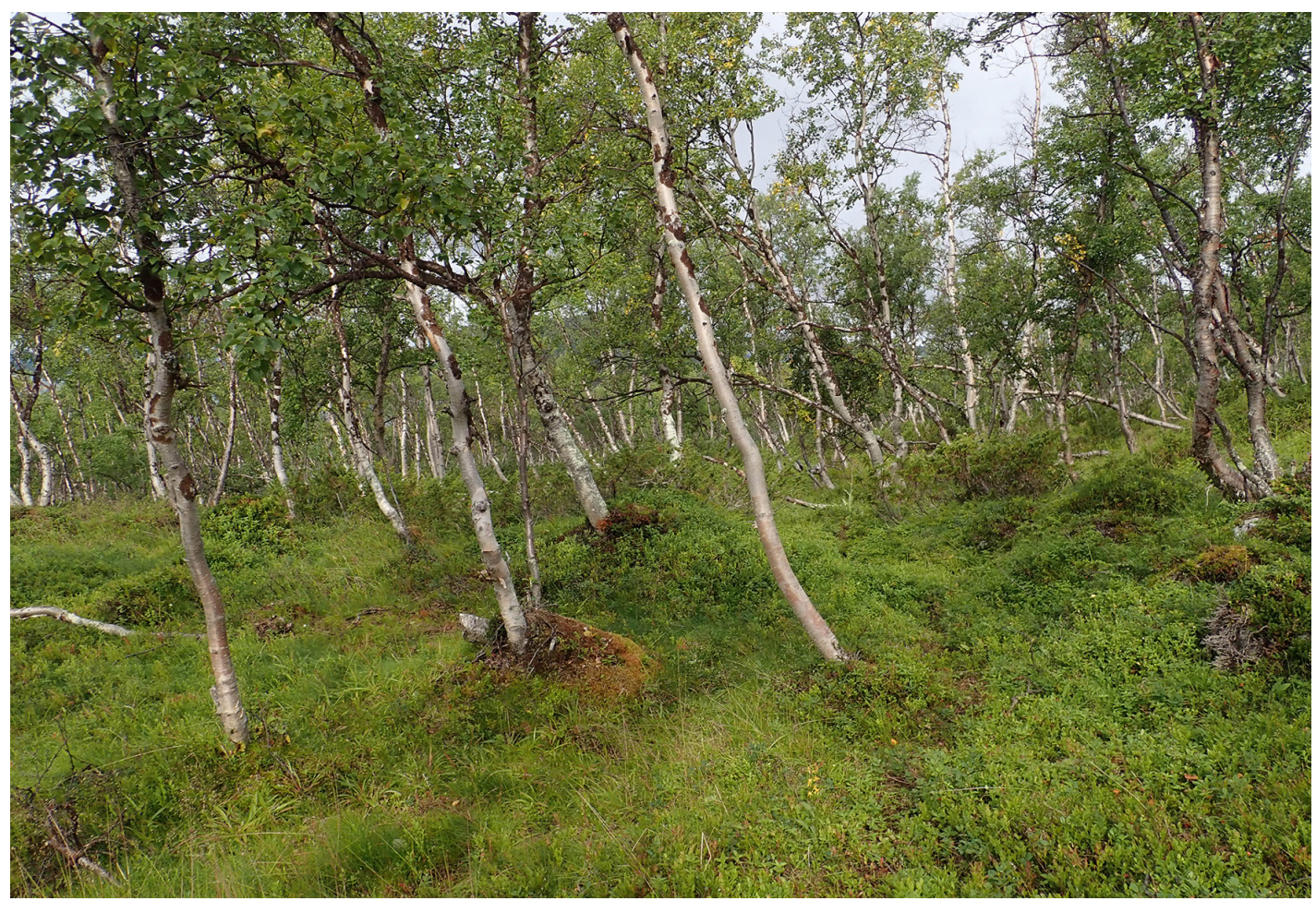

Fig. 5. View from Saana subalpine birch forest in Kilpisjärvi, the type locality of H. betulae, showing the smaller elevations in the vegetation from where on the base or side the specimens were found fruiting.

be overlooked as the subalpine Betula forests in late season traditionally have not been so frequently visited by mycologists. Rarity in fruit body production may also depend on yearly variations in weather conditions since such variation is known to strongly influence fungal fruiting in subalpine forests (Ohenoja \& Metsänheimo 1982). The year 1979, when the species was observed for the first time, it was the top year for fungal fruiting in Kilpisjärvi. Also, 1983 and 1985 were documented good years for the fungi. Other mycorrhizal species fruiting in close neighborhood of Hygrophorus betulae were Cortinarius septentrionalis, C. cinnamomeus, C. croceus, C. caperatus, Lactarius vietus, L. trivialis, Russula versicolor and Tricholoma virgatum, and of saprotrophic species Clitocybe candicans and Gymnopus dryophilus. None of these are known to be especially nutrient demanding species.

Hygrophorus betulae is a slender pale/whitish, olive-grey tinged species with a distinctly glutinous cap and stipe in moist weather. In habitus it is rather similar to H. mesothephrus (Fig. 3A), but paler and with the central disc colour more similar to $\mathrm{H}$. olivaceoalbus (Fig. 3B). The species is growing solitary or in small groups in dryish subalpine Betula pubescens forest (Fig. 5), always fruiting from the base or side of smaller elevations in the vegetation. Observations and collections were made from late August to mid-September.

In the phylogenetic analysis $H$. betulae is recovered close to H. mesotephrus (Fig. 1) a species that in the Nordic countries is associated with older Fagus forests on calcareous ground (Larsson et al. 2011). There are notations of H. mesotephrus from Quercus forests in Southern Europe (Candusso 1997, Kovalenko 2012) but no such material was available for comparison in this study. Also H. mesotephrus is regarded as rare species. The sequence deposited in GenBank and named $H$. cf. mesotephrus, is placed as a sister species to $H$. betulae (Fig. 1). It originates from Tennessee, USA, and was collected in mixed woods. 


\section{Acknowledgments}

The curator of herbarium OULU is gratefully acknowledged for arranging loan. Financial support was received from Carl Tryggers Stiftelse för Vetenskaplig Forskning and The Swedish Taxonomy Initiative, ArtDatabanken SLU Uppsala. The fieldwork at Kilpisjärvi in $1976-78$ was sponsored by the Academy of Finland and the Forest Research Institute. In 1983 financial support was obtained from the Emil Aaltonen Foundation.

\section{References}

Candusso, M. 1997: Hygrophorus s. I. Fungi Europei Vol 6. Libreria Basso, Alassio.

Clark, K., Karsch-Mizrachi, Lipman, D.J., Ostell, J. \& Sayers, E. 2016: Genbank. - Nucleic Acid Research 44, Database issue: D67-D72. https://doi.org/10.1093/nar/gkv1276

Hesler, L.R. \& Smith, A.H. 1963. North American species in Hygrophorus. Kingsport Press, Knoxville.

Hämet-Ahti, L. 1963: Zonation of mountain birch forests in northernmost Fennoscandia. - Annales Botanici Societatis Zoologicae-Botanicae Fennicae "Vanamo" 34: 1-127.

Katoh, K. \& Standley, D.M. 2013: MAFFT multiple sequence alignment software version 7, improvements in performance and usability. - Molecular Biology and Evolution. https://doi. org $/ 10.1093 / \mathrm{molbev} / \mathrm{mst} 010$

Kovalenko, A. 2012: Hygrophorus Fr. In: Knudsen H, Vesterholt J. (Eds.) Funga Nordica. Agaricoid, boletoid, cyphelloid and gasteroid genera, Nordsvamp, Copenhagen, pp. 282-293.

Larsson, A. 2014: AliView: a fast and lightweight alignment viewer and editor for large data sets. - Bioinformatics 22: 3276-3278. https://doi.org/10.1093/bioinformatics/btu531

Larsson, E. \& Bendiksen K. 2011: Upprop om skogsvaxskivlingar (Hygrophorus) i fälllbjörkskog. - Svensk Mykologisk Tidskrift 32: 22

Larsson, E., Campo, E. \& Carbone, M. 2014: Hygrophorus exiguus, a new species in subgenus Colorati section Olivaceoumbrini, subsection Tephroleuci. - Karstenia 54: 41-48.

Larsson, E., Jacobsson, S. \& Stridvall, A. 2011: Släktet Hygrophorus, Skogsvaxskivlingar i Sverige. En fältguide till SMF:s svampväkteri. - Mykologiska Publikationer 3: 1-56, ISSN 1654-546x.
Larsson, E., Kleine, J., Jacobsson, S. \& Krikorev, M. 2018. Diversity within the Hygrophorus agathosmus group (Basidiomycota, Agaricales) in Northern Europe. - Mycological Progress 17:1293-1304.

Larsson. E., Vauras, J. \& Cripps, C.L. 2018: Inocybe praetervisa group - a clade of four closely related species with partly different geographical distribution ranges in Europe. - Mycoscience 59: $277-287$.

Lodge, D.J., Padamsee, M., Matheny, P.B., Aime, M.C., Cantrell, S.A., Boertmann, D., Kovalenko, A., Vizzini, A., Dentinger, B.T.M., Kirk, P.M., Ainsworth, A.M., Moncalvo, J.-M., Vilgalys, R., Larsson, E., Lücking, R., Griffith, G.W., Smith, M.E., Norvell, L.L., Desjardin, D.E., Redhead, S.A., Ovrebo, C.L., Lickey, E.B., Ercole, E., Hughe, K.W., Courtecuisse, R., Young, A., Binder, M., Minnis, A.M., Lindner, D.L., Ortiz-Santana, B., Haight, J., Læssøe, T., Baroni, T.J., Geml, J. \& Hattori, T. 2014: Molecular phylogeny, morphology, pigment chemistry and ecology in Hygrophoraceae (Agaricales). - Fungal Diversity 64: 1-99.

Moreau, P.-A., Bellanger, J.-M., Lebeuf, R., Athanassiou, Z., Athanasiades, A., Lambert, H., Schwartz, C., Larsson, E., \& Loizides, M. 2018: Hidden diversity uncovered in Hygrophorus sect. Aurei (Hygrophoraceae), including the Mediterranean $\mathrm{H}$. meridionalis and the North American $\mathrm{H}$. boyeri spp. nov.

- Fungal Biology 122: 817-836.

Ohenoja, E. \& Metsänheimo, K. 1982: Phenology and fruiting body production of macrofungi in subarctic Finnish Lapland. - in Laursen, G. A. \& Ammirati J. F. (eds.): The First International Symposium on Arcto-Alpine Mycology, Barrow Alaska, 16-23 August 1980: 390-409.

Swofford, D.L. 2003: PAUP*. Phylogenetic Analysis Using Parsimony (* and Other Methods). Version 4. Sinauer Associates, Sunderland, MA.

Uusinoka, R. 1980: Kilpisjärven alueen kallioperästä ja sen vaikutuksesta pinnanmuodostukseen (The bedrock and its influence on the land forms of the Kilpisjärvi area, NW Finland.) - Luonnon Tutkija 84: 2-6. 